\title{
Safety of Birth Control and Contraception: Pharmaceutical Companies on the Testing Bench
}

\author{
Kurt Kraetschmer MD, PhD* \\ Department of Pharmacology, Austrian-American Medical Research Institute
}

*Corresponding author: Kurt Kraetschmer, Department of Pharmacology, Austrian-American Medical Research Institute

\begin{abstract}
Aim: On the background of reports concerning harm to the health of users of a contraceptive product, the paper aims at emphasizing the manufacturers' responsibility to warrant safe use of contraceptive pills and devices.

Method: The method consists in an analysis of sources of information commonly used by women and their healthcare providers, ie, "information for use" provided by manufacturers and statements by renowned agencies, such as WHO, FDA, National Center for Health Research, and CDC. Also, research publications in scholarly journals are critically analysed.

Results: Presently, women do not receive information necessary for the safe use of contraceptive pills and devices -- neither from all pharmaceutical companies nor from healthcare providers.

Conclusion: Comprehensive, complete, and reliable information on all available methods of contraception is difficult to obtain. Pharmaceutical companies should be obliged by law to inform the users of their products in a comprehensible manner about all risks and potential complications without using a confusing, deceptive, or misleading vocabulary.
\end{abstract}

\section{Materials}

Material used comprises primarily information provided by manufacturers in packaging labels and by the FDA in various publications. In instances where it seems appropriate, pertinent scholarly articles published in the most prestigious professional journals are critically analysed.

\section{Methods}

The method consists in an analysis of information provided by various sources, such as manufacturers, FDA, scholarly articles, and popularizing publications emanating from academic institutions and clinics. This information is assessed by analyzing the nomenclature used and by evaluating the reliability of data presented. Criteria applied are principles of evidence-based research.

\section{Findings}

Pharmaceutical companies frequently fail to provide comprehensive and comprehensible information for the consumer, and users of their products are not always enabled to make an intelligent choice, as is required by the principle of informed consent.

\section{Discussion}

Recently, one of the world's leading pharmaceutical companies became the target of press reports commenting on complaints about severe adverse events associated with the company's product for permanent contraception. According to these reports, thousands of women experienced severe medical problems and filed lawsuits against the company in the US and in other countries: "The implant has had a troubled history. It has been the subject of an estimated 16,000 lawsuits or claims filed by women who reported severe injuries, including perforation of the uterus and the fallopian tubes. Several deaths, including of a few infants, have also been attributed to the device or to complications from it [1]." In Australia the device had been withdrawn already in 2017, after women complained about severe harm caused by the implant: "The device, known as Essure, is ... intended to block the fallopian tubes and permanently prevent pregnancy. But there have been reports women experienced changes in menstrual bleeding, unintended pregnancy, chronic pain, perforation and migration of the device, allergic reactions and immune-type reactions after being implanted 
with the device, which is manufactured by the pharmaceutical company Bayer [2]."

\section{The Manufacturer's Description of the Implant for Sterilization and INSTRUCTIONS for Use}

The medical and legal problems, including of class-actions [3], impacting on the company's business were due to a small nickeltitanium coil designed for permanent contraception by way of sterilization. According to the company's product description, the device is an insert, ie, a soft flexible foreign object that is inserted into each one of the fallopian tubes. The insert is composed of a Nitinol (nickel-titanium alloy) outer coil and an inner coil of 316L stainless steel enclosed by polyethylene terephthalate (PET) fibers. In addition, it contains platinum marker bands and a solder made of silver-tin [4]. According to the manufacturer's product description, the length of the insert is $4 \mathrm{~cm}$, and its diameter in the wound-down configuration is $0.8 \mathrm{~mm}$ [4]. When released, the outer coil expands in diameter up to $2.0 \mathrm{~mm}$ and conforms itself to the shape and diameter of the individual patient's fallopian tubes [4]. In its marketing strategy, the company emphasized the uniqueness of the non-incisional device and its approval by the FDA. "Essure is the only FDA-approved non-incisional form of permanent birth control [5]." Concerning the mechanism of action, the company specified that the "Essure system" is intended for permanent contraception by means of a "physical occlusion of the fallopian tubes [4]." Placement of the Essure-system is accomplished through a transvaginal manoeuvre whereby the flexible spring-like insert is placed into the lumen of the proximal portion of the fallopian tube where it anchors upon release. Upon deployment, the outer coil expands, and by pushing against the wall of the fallopian tube it anchors the device acutely in the lumen of the fallopian tube [4]. Dynamic anchoring in the fallopian tube is followed by occlusion of the fallopian tube through a benign tissue in-growth that leads to contraception through sterilization. This "elicited" in-growth of benign tissue provides a permanent occlusion of the lumen of the fallopian tube and effects permanent contraception [4]. Although the company felt compelled to withdraw the product from the US market by the end of 2018 owing to declining sales, it continued to insist on the safety and efficacy of the device. In its final statement announcing the withdrawal from the US market, the company underscored one more time the safety and efficacy of the device by stressing the research undertaken, which involved more than 200,000 women. Allegedly, the benefit-risk profile of the product had remained unchanged and the company continued to stand behind the efficacy and safety of the device, which has been demonstrated by research undertaken not only by the company itself but also by independent medical researchers over the past twenty years [5]. The company's strongest argument for the safety of the device is a statement made by the FDA drawing attention to a comparison of benefits and risks. "The FDA has maintained for several years that the benefits of Essure outweigh its risks [4]."

It should be noted that despite this insistence on the safety of the device the company felt compelled to issue a warning about adverse events which, in the consumer's understanding, is irreconcilable with the characterization "safe." The safety information, including an explicit warning, specifies that some women using the device had experienced most serious adverse events such as perforation of the fallopian tube and the uterus, migration of the device to the abdominal or pelvic cavity, enduring pain, and allergic as well as hypersensitivity reactions. The company specifies that surgery will be necessary if the device has to be removed. Needless to say, the company requests that these most serious complications be communicated to potential users of the device. Addressed is this request apparently to the physicians performing the insertion as they play a pivotal role in communicating benefits and risks to their patients [5]. Besides issuing such a special safety information, the company also draws attention to immuno-suppressants and warns about allergies to nickel, platinum, titanium, metal, polyester fibers, stainless steel, silver-tin, or other component parts of the device.

Complications is possible, the company specifies, not only due to the already inserted device but also during the insertion procedure and immediately afterwards. During the procedure it is possible that the device is placed incorrectly, that parts of it break off, and that perforation through the hysteroscope occurs with ensuing need for surgery. Perforation during insertion occurred in $1.8 \%$ of the participants in the pre-marketing study. Perforation can result in bleeding and in injury to bladder or bowel. In case of breakage, removal of the pieces is required. Also during the procedure, mild to moderate pain was experienced by $9.3 \%$ of the participants in the pre-marketing study. Complications during insertion can be due also to the anaesthesia administered by the physician [5]. Subsequent to the insertion procedure, pain, cramping, and vaginal bleeding may occur. $12.9 \%$ of the women in the pre-marketing study experienced mild to moderate pain, $29.6 \%$ cramping, and $6.8 \%$ vaginal bleeding. Also reported were pelvic or back discomfort for a few days. $10.8 \%$ of the women experienced headaches, nausea and/or vomiting. Dizziness and/or fainting is also possible. In rare cases, the company warns, the insert might be expelled from a woman's body [5].

Not only during insertion and immediately afterwards but also several weeks later the possibility of adverse events still exists, especially during the so-called Essure Confirmation Test. As one of these tests requires an x-ray, the patient is exposed to low levels of radiation. Owing to this test, some women may experience nausea and/or vomiting, cramping, dizziness and/or fainting, pain or discomfort. In rare cases, patients may experience spotting and/or infection [5]. In addition to adverse events during the insertion, after insertion, and during the confirmation test, there is risks which is considered long-term by the company. The most common are acute or persistent pain and allergic reactions to any of the component parts of the device with symptoms such as swelling, itching, hives (urticaria), and rash. The most perilous risk is ectopic pregnancy, and, as the company warns, "this can be life- threatening [5]" and can necessitate surgery for removal of the device. Concerning special populations, the company specifies that neither safety nor efficacy have been established for women under 21 or over 45 years of age [5]. In view of this restriction regarding special populations, it seems self-explanatory that the device should not be used for programs in the area of teenage-pregnancy. 
As a particular safety measure, the company requires that the insertion procedure be restricted to doctors who are competent hysteroscopists. The company also explicates that according to Federal Law, sale of the device is possible only upon the order of a physician, and only those physicians who are competent hysteroscopists may employ it. Employment by a physician too is restricted to those physicians who have read and comprehended INSTRUCTIONS for use together with a training manual. In addition, they must have completed successfully a training program which includes preceptoring in placement until competence is accomplished (ordinarily 5 cases) [5]. As can be seen from the above citations, the company endeavors to provide comprehensive information on the device and mentions also the death-bearing risk of an ectopic pregnancy. At the same time, however, it appears from a consumer's viewpoint that the information is not always as comprehensible and transparent as desired. From an ethical perspective one could even argue that it does not stand up to the requirements of the principle of informed consent, which stipulates that the patient be enabled to make "an intelligent choice [6]." The above mentioned information for use furnished by the company has become the target of criticism emanating from highest authorities in matters of health research, namely the National Center for Health Research. According to press reports, the company's information was criticised as being too long, technical and confusing: "How many people do you know who would carefully read a 22-page document before signing it?' said Diana Zuckerman, president of the National Center for Health Research, a consumer advocacy group. 'In addition to being much too long and technical, the information provided will be confusing to many consumers [1]."

\section{Deficits in the Information for Use Provided by the Manufacturer}

Given the authoritative role played by the National Center for Health Research in matters of health and consumer advocacy, it seems necessary to verify the validity of the criticism voiced. What catches the eye of the critical reader in the first place, is the explanation regarding the mechanism of action furnished by the company. For this explanation a terminology is used which might be confusing not only to the average consumer but even to educated healthcare providers. The description of the occlusion of the fallopian tube, which is the fundamental process for the contraceptive effect, lacks clarity because it uses the terminology "elicits a benign tissue in-growth." From a physiological viewpoint the causal agent and the process of the mentioned tissue in-growth is unresolved [4]. In a different context, tubal occlusion and tissue in-growth are explained with reference to PET, ie, "polyethylene terephthalate fibers [4]". Allegedly, these fibers cause tissue ingrowth which facilitates not only retention of the insert but als tubal occlusion [4]. Not only from a physiological but also from a biological viewpoint it is difficult to understand how a device can "elicit" a benign tissue in-growth. Moreover, whether tissue is benign and not malignant can be determined only through pathology on the basis of a biopsy and not through a theoretical assumption a priori. It is not surprising therefore that alternative explanations have been provided which use the vocabulary "inflammation" and "fibrotic" ingrowth: "The small, flexible inserts are made from polyester fibers, nickel-titanium, stainless steel and solder. The insert contains inner polyethylene terephthalate fibers to induce inflammation, causing a benign fibrotic ingrowth [7]."

Press reports too avoided the expression "in-growth" and spoke of "scar" tissue, ie, tissue which results from a wound. "The Essure implant consists of two small coils made of a nickel alloy and a polytester-like /sic!/ fiber. It is placed through the vagina into the fallopian tubes, and is designed to create an inflammatory response that causes scar tissue to form, blocking the tubes [8]." By medical definition, a scar is "a permanent mark resulting from a wound or disease process in tissue [9]." If the insert does in fact cause a wound, ethical standards require that the consumer be informed accordingly. As is common knowledge, an inflammation involves a number of processes, such as vasoconstriction followed by vasodilatation, stasis, hyperemia, accumulation of leukocytes, exudation of fluid, and deposition of fibrin, including repair processes such as production of new capillaries and fibroblasts, organization, and cicatrization. From a physiological perspective an inflammation is indeed considered a serious reaction. "Inflammation is a complex localized response to foreign substances ... It includes a sequence of reactions initially involving neutrophils, adhesion molecules, complement, and IgG. PAF [Platelet- Activating Factor], an agent with potent inflammatory effects ... also plays a role. Later, monocytes and lymphocytes are involved. Cytokines released from these cells up-regulate relevant CAMs [Cell Adhesion Molecules]. Arterioles in the inflamed area dilate, and capillary permeability is increased [10]."

It is not only the explanation concerning mechanism of action that leaves the consumer unsatisfied; the description of adverse events and potential complications too seems unsatisfactory. In contrast to the limited number of adverse events described by the manufacturer, a popularizing internet publication describes a wide array of risks, such as perforation, expulsion, or unsatisfactory location of the insert; punctured uterine wall; pregnancy and increased risk of ectopic pregnancy; pain, cramping, and vaginal bleeding; change of menstrual patterns, ie, light periods at first, then longer periods with heavier bleeding lasting up to 6 or 8 weeks (due to switching to a non-hormonal form of contraception); nausea or vomiting; vasovagal response (fainting); allergic reaction to a material contained in the insert; heightened response to other allergens; heavy metal toxicity: rash or pruritus; brain fog; symptoms of autoimmune disease; weight gain; anxiety or depression; hair loss; numbness of extremities; joint pain; back pain; and suicidal thoughts [7]. As can be seen from the foregoing analysis, the consumer is confronted with a considerable array of open questions when seeking enlightenment in the instructions furnished by the manufacturer of the Essure implant. An even less satisfying information for the user is provided by the manufacturer of a copper-containing intrauterine device which is designated as an "insert" although its insertion procedure is identical to an implantation. 


\section{An Implant in Disguise of an Insert}

The information leaflet provided by the company describes the device as an insert that has to be inserted in the wall of the uterus. "GyneFix is inserted in the wall of the uterus (womb) [11]." This description is confusing not only to the unexperienced consumer but also to the well-trained gynecologist who is convinced that an insert can be inserted only into a cavity and not into a wall, as is the case with the traditional intrauterine devices or with a diaphragm that is inserted into the vagina. Clearly, if a device is implanted into the uterine wall, it should be designated as an implant, and the question arises whether the company uses the incorrect term "insert" to give the consumer the impression that implantation of the device is as harmless as insertion of a diaphragm. The company's claim of circumventing the feared complication of expulsion makes it clear again that the device is implanted and not inserted. "GyneFix consists of 4 (GyneFix? 200) or 6 (GyneFix? 330) copper tubes which are threaded on a length of surgical suture. A tiny knot at the upper end of the thread keeps the IUD in place. This special characteristic of the device makes expulsion virtually impossible [11]." As can be seen from this description of the "special characteristics" of the device a serious lack of scientific data confuses the reader because the vocabulary "tiny" leaves the door wide open for misinterpretations. As every consumer knows, in describing correctly the characteristics of a device, such as length, width, diameter, etc, the use of international units is indispensable. When the consumer inquiries about the innovative aspect of the device she is informed about the deficits of so-called "older" devices, which, alas, are not identified. "However older intrauterine devices (IUDs) were not favoured by women, many of whom complained of pain, discomfort, heavy bleeding and unintended expulsion in use [11]."

This criticism of "older" devices, however, stands in sharp contrast to studies where these "older" devices are hailed as safe and efficient. Thus, in 2017 authors of a publication devoted to Long-Acting Reversible Contraception (LARC), appearing in one of the world's leading medical journals, claimed that LARC can be used safely by almost all women and concluded: "All adolescents and adult women should be informed about the availability of LARC methods, given their extremely high effectiveness, safety, and high rate of continuation [12]." In view of the alleged drawbacks of older devices the manufacturer of GyneFix feels entitled to emphasize the advantages of its own product which is considered free of any trouble. "The new generation GyneFix has been specially designed to be virtually trouble free whilst maintaining the superior levels of reliability, ease of use and spontaneity in relationships which women and their partners welcome [11]." The manufacturer's claim that its product is "trouble free" perplexes the reader because it has been known for a long time that intrauterine devices are generally plagued by infections. As early as 1997 this disadvantage had been underscored as an evidence-based truth in physiology: "Intrauterine implantation of pieces of metal or plastic (intrauterine devices, IUDs) has been used in programs aimed at controlling population growth. . Their usefulness is limited by their tendency to cause intrauterine infections [10]." Besides ascending infection, expulsion has been highlighted as one of the most feared complications by German authors in 2000 [13]. In addition to ascending infections and expulsion, other complications have been described as early as 2003 by British authors, namely perforations and adhesions. In their publication devoted explicitly to perforations with GyneFix, the authors not only discussed six cases of perforation but drew attention also to adhesions as one of the most common adverse events of copper-containing intrauterine devices. "Copper IUDs such as the GyneFix are thought to predispose the patient to adhesions once inside the peritoneal cavity [14]." As can be seen from the analysis of the information leaflet provided by the manufacturer of GyneFix, there is sufficient reason for the consumer to question the safety of the product and to turn to alternatives. An increasing number of women is indeed exploring other options of contraception, especially those prioritizing safety.

\section{Women in Search of "Safe" Methods of Birth Control and Contraception}

In view of severe adverse events, risks, potential complications and impact on the quality of life [15] associated with LARC and other hormonal methods, women need assistance in their search for alternative, safe methods. Their pursuits in finding the personally most suitable method of contraception are nowadays facilitated by tables, ratings, and rankings of contraceptive methods. Such instruments are helpful not only for women but can assist also doctors in the clinical practice where time is at a premium. Rankings giving highest priority to the parameter safety can offer quite a number of efficient options -- provided users are sufficiently motivated to adhere to the INSTRUCTIONS so that perfect use estimates can be accomplished. Indeed, the most efficient of these methods has been attributed a perfect use estimate of 0.4 per cent by research in Contraceptive Technology in 2011 [16] and a Pearl Index of 0.8 by German authors in 2000 [13] (Table 1). Additional advantages of some of the safest methods have been highlighted by the American Congress of Obstetricians and Gynecologists (ACOG) and the Centers for Disease Control (CDC). The former emphasized cost and convenience by stating: "They cost very little . . Many women like the fact that fertility awareness is a form of birth control that does not involve the use of medications or devices [17]." Similarly, the Centers for Disease Control (CDC) underscored their convenience and efficacy. "Newest methods (Standard Days Method and Two-Day Method) may be the easiest to use and consequently more effective [18]." 
Table 1: Safety-Efficacy-Convenience/Satisfaction-Cost Ranking (SECCR).

\begin{tabular}{|c|c|c|c|c|}
\hline Method & $\begin{array}{l}\text { Safety (no } \\
\text { harm in the } \\
\text { sense of "nil } \\
\text { nocere") }\end{array}$ & $\begin{array}{l}\text { Efficacy Perfect- } \\
\text { Typical use }\end{array}$ & $\begin{array}{c}\text { Convenience } \\
\text { Satisfaction ( } \% \text { women } \\
\text { continuing after one } \\
\text { year) }\end{array}$ & Cost \& Specifications \\
\hline Symptothermal & High & $0.4-24$ & High? & $\begin{array}{l}\text { No cost. Body temperature must be measured, } \\
\text { cervical mucus must be observed (clear } \\
\text { texture), cervix must be palpated (soft } \\
\text { consistency and open). }\end{array}$ \\
\hline \multirow[t]{2}{*}{$\begin{array}{l}\text { Ovulation (based on cervical } \\
\text { mucus) }\end{array}$} & High & $3-24$ & High & No cost. \\
\hline & & & $?$ & $\begin{array}{l}\text { Cervical mucus must be observed } \\
\text { ("spinnbarkeit"). }\end{array}$ \\
\hline \multirow[t]{2}{*}{$\begin{array}{l}\text { TwoDay (based on cervical } \\
\text { mucus) }\end{array}$} & High & $4-24$ & High & No cost. \\
\hline & & & $?$ & $\begin{array}{l}\text { Coitus must be avoided during fertile days. } \\
\text { Fertile days determined by presence of cervical } \\
\text { mucus (color and consistency). Coitus may } \\
\text { be resumed after } 2 \text { consecutive dry days (or } \\
\text { absence of secretion). }\end{array}$ \\
\hline \multirow[t]{2}{*}{$\begin{array}{l}\text { Standard Days Method (SDM) - } \\
\text { based on calendar }\end{array}$} & High & $5-24$ & High & No cost. \\
\hline & & & $?$ & $\begin{array}{l}\text { Fertile period is tracked and coitus avoided } \\
\text { (usually days 8-19 of each 26-32 day cycle). }\end{array}$ \\
\hline \multirow[t]{2}{*}{ Basal Body Temperature (BBT) } & High & $1-25$ & High & No cost. \\
\hline & & & $?$ & $\begin{array}{l}\text { Fertile phase has passed when body } \\
\text { temperature has risen }(0.2-0.5 ? \mathrm{C}) \text { and } \\
\text { remained such for } 3 \text { days. Conception is } \\
\text { unlikely from } 4 \text { th day following rise of } \\
\text { temperature until next menstruation. }\end{array}$ \\
\hline \multirow[t]{2}{*}{ Calendar (rhythm) method } & High & $9-25$ & High & No cost. \\
\hline & & & $?$ & $\begin{array}{l}\text { Menstrual cycle is monitored for at least } 6 \\
\text { months. } 18 \text { is subtracted from shortest cycle } \\
\text { (this is the estimated first fertile day). } 11 \text { is } \\
\text { subtracted from the longest cycle (this is the } \\
\text { estimated last fertile day). Caution when drugs } \\
\text { are used (NSAID, certain antibiotics, anxiolytics, } \\
\text { anti-depressants, etc.). }\end{array}$ \\
\hline $\begin{array}{l}\text { Withdrawal (coitus } \\
\text { INTERRUPTUS) }\end{array}$ & High & $4-22$ & High $46 \%$ & Semen must be discharged outside the vagina. \\
\hline Lactational Amenorrhea (LAM) & & & & $\begin{array}{c}\text { Effective in preventing ovulation as long } \\
\text { as monthly bleeding has not yet returned. } \\
\text { Requiresexclusive breastfeeding day and night } \\
\text { of infant less than } 6 \text { months old }\end{array}$ \\
\hline \multirow[t]{2}{*}{ Male condoms } & $\begin{array}{c}\text { Moderate } \\
\text { (Latex allergy) }\end{array}$ & $2-18 / 43 \%$ & High & Low cost. \\
\hline & & & & $\begin{array}{l}\text { Protects against sexually transmitted diseases } \\
\text { (STD) including HIV. }\end{array}$ \\
\hline \multirow[t]{2}{*}{$\begin{array}{l}\text { Implant (Small, flexible rod } \\
\text { or capsule placed under the } \\
\text { skin of the upper arm; contains } \\
\text { progestogen hormone only). }\end{array}$} & Moderate & $0.05-0.05$ & High & High cost. \\
\hline & & & $84 \%$ & $\begin{array}{l}\text { Implanted by clinician. Irregular vaginal } \\
\text { bleeding common. }\end{array}$ \\
\hline \multirow{2}{*}{$\begin{array}{l}\text { Mirena (LNG) Intrauterine } \\
\text { device (IUD) (T-shaped plastic } \\
\text { device inserted into the uterus; } \\
\text { releases continuously small } \\
\text { amounts of levonorgestrel). }\end{array}$} & Moderate & $0.2-0.2 / 80 \%$ & Moderate & High cost. \\
\hline & & & & $\begin{array}{l}\text { Prevents contact between sperm and egg by } \\
\text { thickening cervical mucus. Amenorrhea. }\end{array}$ \\
\hline ParaGard (copper IUD) & Moderate & $0.6-0.8 / 78 \% 8$ & Moderate & High cost. \\
\hline
\end{tabular}




\begin{tabular}{|c|c|c|c|c|}
\hline & & & & Copper component damages sperms. \\
\hline Depo-Provera & Moderate & $0.2-6 / 56 \%$ & Moderate & High cost. \\
\hline \multirow[t]{2}{*}{$\begin{array}{l}\text { Combined oral contraceptives } \\
\text { (COCs) }=\text { "the pill" }\end{array}$} & Moderate & $0.3-9 / 67 \%$ & Moderate & Moderate cost. \\
\hline & & & & Contains estrogen and progestogen. \\
\hline \multirow[t]{2}{*}{$\begin{array}{l}\text { Progestogen-only pill (POP) or } \\
\text { "minipill" }\end{array}$} & Moderate & $1-3(10) / 67 \%$ & Moderate & Moderate cost. \\
\hline & & & & $\begin{array}{l}\text { Thickens cervical mucus and prevents } \\
\text { ovulation. }\end{array}$ \\
\hline Evra patch & Moderate & $0.3-9 / 67 \%$ & Moderate & High cost. \\
\hline \multirow[t]{2}{*}{ NuvaRing } & Moderate & $0.3-9 / 67 \%$ & Moderate & \\
\hline & & & $67 \%$ & High cost. \\
\hline \multirow{2}{*}{$\begin{array}{l}\text { Combined contraceptive patch } \\
\text { and combined contraceptive } \\
\text { vaginal ring (CVR) }\end{array}$} & Moderate & $1-8(?)$ & Low & High cost. \\
\hline & & $\begin{array}{l}\text { (Research on } \\
\text { efficacy limited). }\end{array}$ & $?$ & $\begin{array}{l}\text { Continuously releases a progestin and an } \\
\text { estrogen directly through the skin (patch) } \\
\text { or from the ring. Pharmaco-kinetic profile } \\
\text { comparable to COCs. }\end{array}$ \\
\hline \multirow[t]{2}{*}{$\begin{array}{l}\text { Monthly injectables or } \\
\text { combined injectable } \\
\text { contraceptives (CIC) }\end{array}$} & Moderate & $1-3$ & Low & High cost. \\
\hline & & & $?$ & $\begin{array}{l}\text { Irregular vaginal bleeding. Injected monthly } \\
\text { into muscle. }\end{array}$ \\
\hline \multirow[t]{2}{*}{ Progestogen-only injectables } & Moderate & $1-3$ & Low & High cost. \\
\hline & & & $?$ & $\begin{array}{l}\text { Injected into the muscle or under the skin every } \\
2 \text { or } 3 \text { months, depending on product. Irregular } \\
\text { vaginal bleeding; delayed return to fertility } \\
\text { after use. }\end{array}$ \\
\hline \multirow[t]{2}{*}{ Diaphragm } & Moderate & $6-12 / 57 \%$ & Low & High cost. \\
\hline & & & $57 \%$ & Must be used for each coitus. \\
\hline \multirow[t]{2}{*}{ Emergency Contraception (EC) } & Moderate - Low & $1-15$ & High & Moderate cost. \\
\hline & & & $?$ & $\begin{array}{c}\text { Pills (ulipristal acetate } 30 \mathrm{mg} \text { or levonorgestrel } \\
1.5 \mathrm{mg} \text { ) must be taken twice to prevent } \\
\text { pregnancy up to } 5 \text { days after coitus. } \\
\text { Alternatively IUD (copper or levonorgestrel) } \\
\text { can be inserted. }\end{array}$ \\
\hline \multirow[t]{2}{*}{ Male sterilization (vasectomy) } & Moderate & $\begin{array}{l}<1 \text { (after } 3 \text {-months } \\
\text { semen evaluation). } \\
\text { 2-3 (without } \\
\text { semen evaluation). }\end{array}$ & High & High cost. \\
\hline & & & $100 \%$ & $\begin{array}{c}\text { Surgical intervention. Permanent contraception } \\
\text { by cutting vas deferens tubes which transport } \\
\text { sperm from the testicles. }\end{array}$ \\
\hline \multirow[t]{2}{*}{$\begin{array}{l}\text { Female sterilization (tubal } \\
\text { ligation) }\end{array}$} & Low & $0.5-0.5$ & High & High cost. \\
\hline & & & $100 \%$ & $\begin{array}{l}\text { Surgical intervention. Permanent contraception } \\
\text { by blocking or cutting the fallopian tubes. }\end{array}$ \\
\hline $\begin{array}{l}\text { Sterilization through creation } \\
\text { of scar tissue (ESSURE) }\end{array}$ & Very low & $?$ & Low? & $\begin{array}{l}\text { Device has been withdrawn from the market in } \\
\text { several countries, including the U.S. }\end{array}$ \\
\hline \multirow[t]{2}{*}{ Sponge } & Moderate & $\begin{array}{l}\text { 20-24 - parous } \\
\text { women } \\
\text { 9-12-nulliparous } \\
\text { women }\end{array}$ & Moderate/36\% & Moderate cost. \\
\hline & & & & To be used for each coitus. \\
\hline Spermicides & Moderate & $18-28$ & High $42 \%$ & Moderate cost. \\
\hline
\end{tabular}




\section{Conclusion and Implications}

The foregoing discussion shows the possible medical and legal reverberations of deficient information regarding safety provided by manufacturers. Regardless of statements made by the FDA and of claims made by the company, the consumer will not be persuaded that a device associated with severe adverse events and potential complications can be designated as safe. From a clinical viewpoint it appears unrealistic to expect doctors, who have to abide by the principle of cost efficiency, to invest their time in complementing information about safety that should have been provided a priori by the manufacturer. Pharmaceutical companies are well-advised to pay heed to DOs and DON'Ts. The latter include ambiguous terminology in describing mechanism of action, belittling adverse events, and withholding information about risks and potential complications. The DOs include complete and comprehensible explanations of mechanism of action; understandable nomenclature for all levels of education; extensive discussion of adverse events, risks, and possible complications; and evidence-based data for claims about the safety of a product. For those women who have turned the back on hormonal contraception information about alternatives should be made available, such as rankings which prioritize safety.

\section{References}

1. (2018) Washington Post, USA.

2. (2018) Mon 13 Aug 201801.40 BST Last modified on Mon 13 Aug 2018 02.55 BST. The Guardian.

3. (2018) birthcontrolproblems.com/australia-essure-class-action. The Guardian.

4. Bayer (2002) Essure permanent birth control. English Copy Text. Printed in USA.
5. Bayer (2018) Bayer to voluntarily discontinue US sales of Essure at end of 2018 for business reasons. Whippany.

6. (1992) Code of Medical Ethics. Current Opinions. American Medical Association. Chicago, Illinois

7. Wikipedia. Essure.

8. (2018) New York Times.

9. (1979) Blakiston's Pocket Medical Dictionary. New York: McGraw-Hill Book Company. ( $4^{\text {th }}$ edn.)

10. Ganong WF (1995) Review of Medical Physiology. Prentice-Hall International Inc Norwalk, CT: Appleton \& Lange. ( $17^{\text {th }}$ edn.).

11. GyneFix Information for the user. CONTREL Manufacturer. CONTREL EUROPE nv Incubatie - en innovatiecentrum. Technologiepark 3 B1 (Universiteit Gent), 9052 Gent (Zwijnaarde).

12. Curtis KM, Peipert JF (2017) Long-Acting Reversible Contraception. N Engl J Med 376(5): 461-468.

13. Gröger S, Grüne B (2000) Kontrazeption. In: Diedrich K, (eds). Gynäkologie und Geburtshilfe : 60-87.

14. Aust TR, Kirwan JN, Herod JJO, McVicker JT (2003) Perforation with the GyneFix? intrauterine implant: is there a common factor. Journal of Family Planning and Reproductive Health Care 29(3): 155-156.

15.Zethraeus N, Dreber A, Ranehill E, Blomberg L, Labrie F, et al. (2017) A first-choice combined oral contraceptive influences general well-being in healthy women: a double-blind, randomized, placebo-controlled trial. Fertility and Sterility 107(5): 1238-1245.

16. Trussell J (2011) Contraceptive efficacy In: Hatcher RA, Trussell J, Nelson AL, Cates W, Kowal D, Policar M (eds.). Contraceptive Technology: Twentieth Revised Edition. New York, USA.

17. American Congress of Obstetricians and Gynecologists (ACOG).

18. (2016) Centers for Disease Control and Prevention. US Medical Eligibility Criteria for Contraceptive Use.

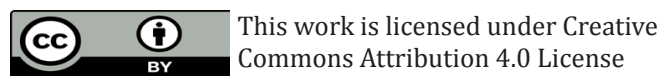

To Submit Your Article Click Here:

Submit Article
DOI: $10.32474 /$ LOJPCR.2019.01.000116

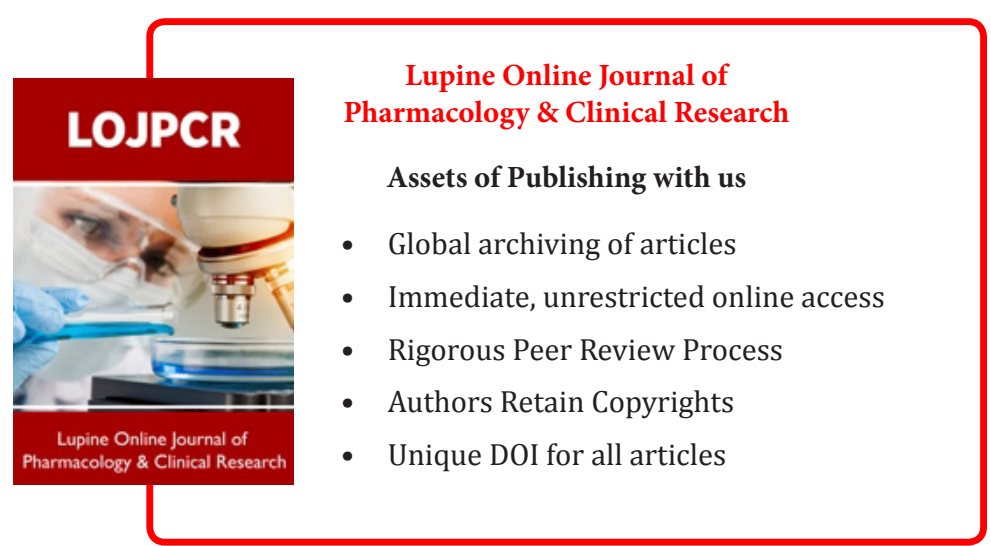

